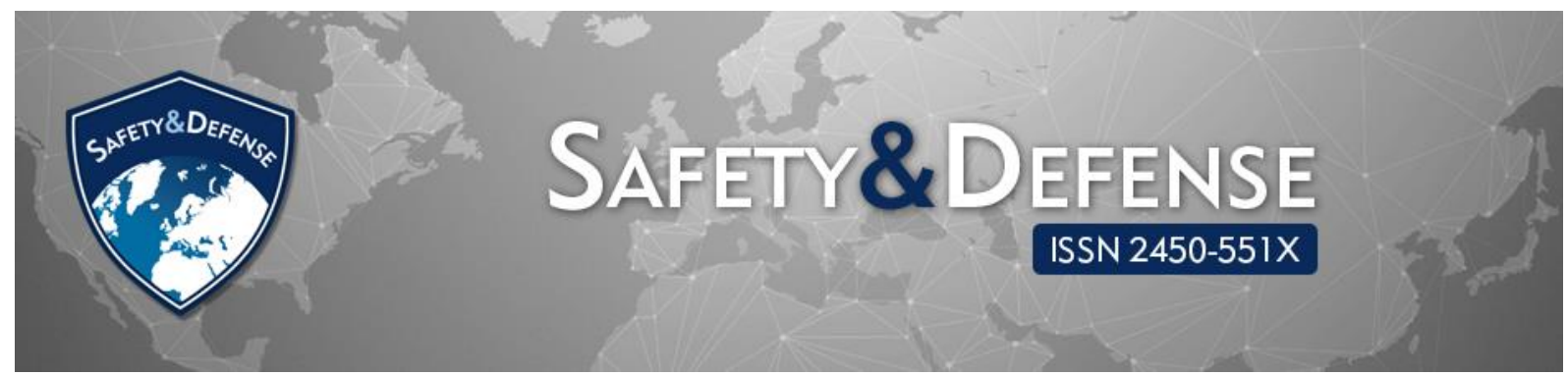

\title{
Air Terrorism as a Threat to the Safety of Air Transport
}

\author{
Jacek PAJĄK \\ General Tadeusz Kościuszko Military University of Land Forces, Wrocław, Poland; \\ jacek.pajak@awl.edu.pl, ORCID: 0ooo-0003-0770-1881
}

DOI: https://doi.org/10.37105/sd.90

\begin{abstract}
The author of this article addresses the issue of the threat posed to air transport security by air terrorism. The main goal of this article is to identify the specific threats arising from air terrorism and examine their implications for the functioning of air transport as a whole. The dangers posed by attacks using hijacked light aircraft as well as large passenger airliners are highlighted. The article is based on the literature study and the author's own analyses of the issue.
\end{abstract}

Keywords: air security, air terrorism, safety of air transport, safety.

\section{Introduction}

The turn of the 2oth and 21st centuries has been a period in human history characterized by dynamic changes in the living conditions of the inhabitants of the Earth. Despite being largely positive, these changes have not been without their negative effects. Globalization is one of many processes that is developing dynamically. It fosters a situation in which state borders do not pose an obstacle to the movement of people or goods of all kinds, whether by sea, air or land. A crucial factor serving to accelerate this process is the communications revolution that is taking place in physical as well as virtual reality. Individual areas of social and economic life are becoming elements of a new, more interdependent system. The globalization of markets is resulting in changes to the scale and nature of activity occurring in international airspace. Air transport, which includes both air travel and air freight, may be defined as the displacement of people or goods via the air by means of aircraft, which is to say airplanes or helicopters. The principal aim of this article is to identify and analyze the spectrum of air terrorism threats 
and their impact on the safety of air transport. The author pays special attention to such counter-measures that may prove effective against the threats posed to air transport safety by air terrorist activity.

The thesis assumes that the phenomenon of air terrorism over the last several decades has become the greatest threat to air transport safety by posing a direct threat to lives of both travelers and ordinary residents who may die as a result of an act of air terror. In addition, there is a noticeable increase in the psychological impact on society and economic impact on the aviation industry.

\section{Identification of threats to air transport safety}

Air transport may be classified as either civil or military. Civil aviation is a widely available means of air transport, comprising Sport Aviation (e.g. gliders), General Aviation (private planes, VIP planes) and Transport Aviation (passengers and freight transport). Military aviation is conducted by individual countries. This type of aviation is commonly used to deliver humanitarian aid, transport political VIPs and escort civil planes with technical problems.

Security threats in airspace can be of various natures and sources. Among them we distinguish, natural threats, the occurrence of which humanity has no control over and which it cannot actually counteract. These are passing meteorites, volcanic eruptions and other cataclysms. Safety may also be adversely affected by inadequately operating and obsolete airborne radio, navigation or meteorological maintenance systems and factors such as faulty traffic control and poor training, fatigue or fatigue of pilots. There were also cases of shooting down aircrafts, including civilian ones, and violating the airspace of other countries. Another important factor determining safety in the airspace is the constantly growing number of aircraft and systematically increasing air traffic. Concomitantly it can be asserted that air transport is state-of-the-art and is the most dynamically developing branch of transport. It is based on sophisticated means of transport, navigation and ground maintenance and it involves enormous financial outlays and highly qualified personnel. Air transport allows one to reach a given destination quickly. As mentioned above, despite its many positive social aspects, air transport is connected with one negative phenomenon, namely air terrorism. That phenomenon poses a threat to the lives of passengers and to the lives of others, who are the potential victims of terrorist attacks by virtue of being in an affected air-space or airport zone.

\section{Terrorists attacks}

The very term "terrorism" is derived from the Latin word terror, which means terror, fear, fear as well as various aspects of violence and rape that cause a feeling of fear. Terrorism is the use of violence, rape, cruelty to intimidate someone (Witkowski, 2000). There are two meanings of this word in Polish. Terror means the use of the violence including rape, cruelty to intimidate the opponent and the very effect of such behavior in the form of terror, fear, dread or intimidation (Terror, 1989). Air terrorism, as one of the phenomena of terrorism, belongs today to the most dangerous social phenomena. It is a deliberate and systematic method used to achieve goals by terrorist groups, and one that is constantly evolving. With a high degree of probability it can be repeated after some of the greatest experts in aviation terrorism in the world: B. Jenkins and P. Wilkinson, that we are currently preparing legally and organizationally only for past terrorist attacks - and not those that will follow. 
This type of crime is an excellent and extremely cheap tool of intimidation, and perhaps above all, international publicity. Suffice it to quote the statement made in 1970 by Dr. George Habasch, the former leader of the People's Front for the Liberation of Palestine.

Hijacking large plane has a greater effect in propaganda and the media than killing one hundred Israelis in a battle (Gotowała, 2006). Therefore, it is almost certain that this phenomenon will continue to be one of the basic instruments for achieving goals by existing or aspiring to such a name international terrorist organizations. In today's world we are dealing with an increase in the field of:

- information exchange;

- moving around;

- transport of goods;

- development of incentives influencing the environment in which we operate.

The main factor influencing the speed of changes is of course, time in these areas of human activity. The speed of movement, the flow of information, or the timely delivery of raw materials for pro-duction, etc., undoubtedly affects the pace of development in almost all spheres of human existence.

Due to this, air transport, and above all civil aviation, is such a very important element defining the way the reality around us functions. It was civil aviation that was and will continue to be the target of terrorist attacks. Therefore, a key element of the state's anti-terrorist security system is the protection of civil aviation - not only and only aircraft, but also airports. The figure below shows the possibilities of carrying out attacks related to the phenomenon of air terrorism.

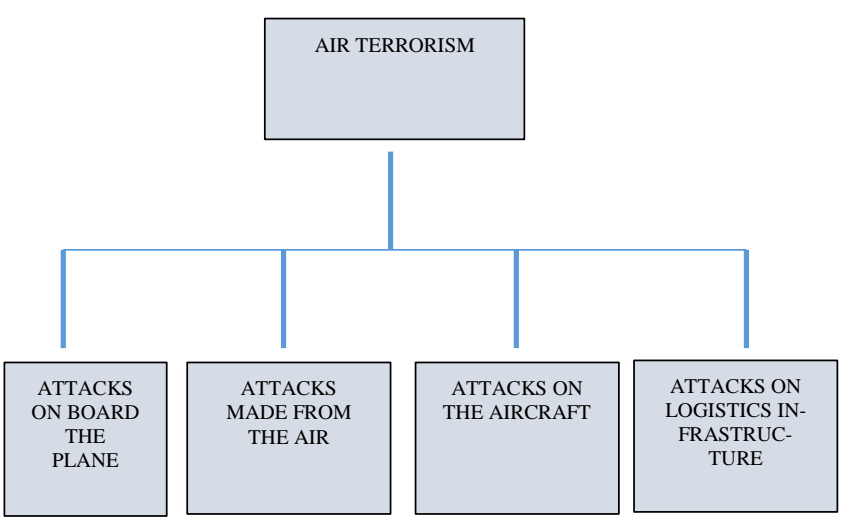

Figure 1. Possibility of attacks - air terrorism

Some researchers describe the phenomenon of terrorism as the new paradigm of war and it is becoming a primary threat for many countries (Marks, 2006; Kingshott, 2003). Counteracting this threat requires not only preventing direct losses to people or damages of an economic nature. The fight against terrorism is also an element of efforts to:

- social and political stability of the state;

- safe development;

- undisturbed course of processes that determine the normal functioning of the community.

It can be seen that over time, various social groups are targets of terrorist attacks. These attacks take more and more massive forms, and terrorism itself is becoming more and more brutal and less and less precise.

Historically, the first recorded hijacking case was the hijacking of a Peruvian airline in 1930. However, based on the data provided by the International Civil Aviation Organization, the first post-war case of "hijacking" involving the unlawful seizure of an aircraft by force or threat was hijacking a plane flying from Macao in 1948. In the following years, we can already observe a jump in the phenomenon, the peak of which took place in 1969, when 80 cases of hijacking were recorded.

Based on an analysis of the motives of air terrorism, it appears that the initially hijacked aircraft were used as a means of transport. They consisted in taking control of the plane by forcing the pilot to change 
course and forcing him to land in another country in order to escape. The planes were then hijacked to take hostages or to destroy an aircraft in order to obtain adequate benefits from the government of the country concerned.

A completely new page in the history of air terrorism was turned by the aforementioned events of September 11, 2001. Then we not only faced a change in the way the attacks were carried out, but also a completely different personal format of the attackers. Not a single plane was hijacked, but four ships. These planes were used as means of destruction for military, public and civil administration purposes. The kidnappers turned out to be educated people at the same time ready to sacrifice their own lives. The world has faced an enormous challenge to define the perpetrator, without which it is impossible to effectively counteract.

Nowadays, terrorism is one of the most dangerous social phenomena in the world and poses a worldwide threat to security. The most developed, wealthy and democratic countries are especially exposed to terrorist attacks of all kinds.

From ancient times, the methods and forms of terrorist activity have developed alongside and keeping pace with those of civilization itself. This kind of activity has, however, always been dominated by brutality and the urge to gain publicity for a cause. Terrorists very often place the issues that they fight for above their own lives and they do not bother about the lives of others. The development of civilization is responsible for the delivery of novel tools and also targets: urban communications systems such as the metro; shopping centers, hotels, passenger ships. Planes have been of great interest to terrorists as potential targets since the 1930s. The incident that took place on the night between 22 and 23 July 1968, when three terrorists from the Popular Front for the Liberation of Palestine took over an Israeli airliner, El Al Flight. El Al Flight 426 was route from Rome to Tel Aviv when the Boeing 707 was hijacked by three terrorists from the PFLP (Popular Front for the Liberation of Palestine), who ordered the pilot to land in Algeria. They had assumed that Yitzhak Rabin, the Israeli ambassador in the USA, would be taking this flight. There were 38 passengers and 10 crew members on board. Negotiations with the hijackers took four days and eventually ended with the release of the hostages $(\mathrm{O} 2,2016)$. This fact marked the beginning of a period in which passenger airplanes became the principal target of terrorist attacks. Over the years, terrorists have extended the range of their attacks upon aviation-related targets. They have turned their attention to airports, aviation infrastructure and the offices of airlines (Wilkinson, and Jenkins, 1999). Rationales for the planning and execution of air terrorist attacks have multiplied. The methods and forms of the attacks themselves have evolved, as has the scale of their impact.

Air terrorism is either directed against aviation-related targets or uses aviation personnel or aircraft equipment instrumentally against targets unrelated to aviation. It can also do both, i.e., use air devices and operational personnel to target other aviation-related targets. Terrorist attacks against civil transport aircraft or air transport systems can use:

- light aircraft;

- transport aircraft;

- civil transport aircraft;

- man-portable air defense;

- man-portable anti-tank systems;

- grenade launchers and firearms;

- explosives;

- anti-personnel mines;

- chemical, biological agents;

- cyberterrorism.

Considering the first item on this list, namely light aircraft. During periods of elevated terrorist threat, the risk of light aircraft or helicopters being used to carry out an attack against civil transport aircraft and/or air transport should be taken extremely seriously as such an attack can be devastating. The events of 11 September 2001 in New York and Washington show just how significant a threat this is. Nowadays terrorist attacks using hijacked light aircraft are facili- 
tated by easy access to unprotected small airdromes and landing strips. For as long as the special protection of such places is not prioritized, the probability of a terrorist attack using light aircraft during periods of elevated threat is going to be high.

The next category to consider is that of civil transport aircraft, such as airliners or other transport aircraft that carry cargo or mail. Nowadays, it is estimated that passenger aircraft in associated airlines number 13 300 , a passenger airline is an airline dedicated to the transport of passengers. There are several types of passenger airlines, mainly: transcontinental, medium and short-range (Domański, 1974), although it is anticipated that the need for such aircraft will decrease and that the number will drop to 28500 in 2026 (Augustyniak, 2008). In the aviation sector, 750 carriers are in operation, carrying 4.5 billion passengers every year. According to estimated data from the Airport International Council (AIC), headquartered in Geneva, the number of travelers using aviation transport will have doubled by 2025 so as to exceed 9 billion passengers (Puls Biznesu, 2007). It should be noticed that these numbers do not involve private carriers and their aircraft.

Such rapid expansion of passenger air transport is a consequence of the corresponding growth in the clientele of low-fare airlines which have come to control one quarter of the market. The prevalence of air transport, with its ever-expanding passenger numbers and air carrier fleets, creates an opportunity which is highly likely to be exploited by terrorists. After 11 September 2001 the strictest security regimes were introduced by aviation authorities all over the world. However, a series of thwarted attempts to hijack civil transport aircraft since then have shown that terrorists are perpetually on the look-out for new methods, forms and ways to take over such aircraft. In Great Britain in August 2006, terrorists tried to take over seven scheduled flights. British intelligence services foiled the attempt of several dozen terrorists to hijack commercial air-liners taking off from Heathrow airport. Terrorists intended to use those aircraft to attack public places located in one of the biggest cities in the USA. Their plans involved using chemical liquid substances trafficked in carry-on luggage to create explosives on the planes (RMF.FM, 2006)

The next attempt to use an airliner, in this instance one belonging to the USA's Northwest Airlines, for a terrorist attack occurred on 23 December 2009. As this plane was landing at the Detroit Airport with 278 passengers and 11 crew members on board, Nigerian bomber Umar Faruk Abdulmutallab, associated with Al-Qaeda, tried to detonate an explosive charge called PETN which was sewn into his clothes. The detonation was supposed to be carried out by means of a syringe containing an incendiary chemical. The attack did not succeed, because instead of exploding, the explosive charge started burning, the terrorist was exposed and in the aftermath, disarmed by passengers. It is noteworthy that the timing of the detonation was designed to maximize casualties by including people on the ground who would have been hit by wreckage from the plane (Wyborcza.pl, 2012).

Over the last several decades, it can be clearly stated that the phenomenon of air terrorism has significantly evolved towards increasing the possibilities of obtaining effects by terrorist organizations, and thus increased the degree of danger for air transport. As it was noted in this part of the article, the evaluation of the phenomenon of air terrorism went towards simultaneous attacks, superterrorism and cyberterrorism.

The threats posed by air terrorism today have consequences such as: a large number of human casualties and direct losses after the attack, long-term economic losses resulting from a decrease in the number of passengers and contractors for the airlines concerned, psychological effects on society, long-term political and social consequences. Of the above-mentioned effects of the threat of air terrorism, only in the case of the first, can clear assumptions in the area of counteraction be defined. (Glen, 2010) 


\section{Counteracting threats in the field of air terrorism}

Currently, in order to improve the safety of air transport, organizational and technical solutions are designed and implemented for air transport in both airplanes and airports. The level of detail of checks at airports from passengers and their luggage to checks around airports and inside airports has generally been increased. It develops and introduces more and more modern and technologically advanced technical control measures. In order to improve the security situation, organizational and technical solutions for air transport, and more specifically for aircraft and airports, are currently being designed and implemented. New security standards involve mounting bulletproof doors and electronic access control into the cockpit. Additionally TV cameras placed in cockpits provide video feeds to Air Traffic Control, and armed agents - the so-called Air Marshals - can be found on board during the flight. Effective technical solutions aimed at increasing the resilience of aircraft in the case of a bomb attack include the widespread deployment of reinforced bulkheads designed to effectively contain an explosion, should a bomb go off in the luggage compartment.

Airport security is similarly being improved through the restriction of parking in areas adjacent to airports and run-ways, the restriction of movement in areas where people wait for the arrival of an aircraft, and the installation of gates that can monitor the temperature of passengers' bodies to detect overexcited persons. An apparatus analyzing the composition of the air is installed to make possible the detection of explosive materials and more detailed control concerning passengers' identity and their luggage.

\section{Summary}

It is undoubtedly noticeable that the threat of air terrorism is multi-faceted and multi-dimensional. Above all, it is international. The process of combating this threat entails significant financial, logistic and organizational consequences, and at the same time, it forces the introduction of new legal regulations. In addition, it is a threat that affects all who travel by air, which translates into disrupting the special and priority role of air transport as the fastest and safest means of movement of people, which in today's dynamic times is undeniably an important factor in the functioning of humanity. In summing up this article, it can be asserted that even the best solutions are not able to provide total security for the aircraft. The implementation of security systems is unfortunately a long-term project and security systems that are being used in individual countries to secure airports and passenger aircraft are characterized by considerable diversity. A key consideration is the level of funding assigned to the creation and maintenance of air security systems. It is still all too likely that an aircraft from a poorly developed country, where the level of security systems for airports and aviation is very low, will be hijacked. Such a flight can then proceed from that poor country to a wealthy country with the aim of staging a terrorist attack against that country's public buildings and/or national monuments.

Undoubtedly the situation mentioned above can happen and must be taken into account by special services responsible for air transport security.

The threat of terrorist attacks is in a constant process of evolution. One should take into account that anyone who travels by air today may be a victim of an attack. Therefore, it is indispensable for the inter-national community and individual countries had effective countermeasures.

A properly functioning state must have an organized system to respond to such dangers. The growing threat of air terrorism is 
leading the international community and individual countries to take political, strategic and tactical actions aimed at neutralizing its effects. Scientists have a significant role to play in building organizational efficiency where such actions are concerned and the results of their research should most certainly be taken into account by decision-makers responsible for implementing new solutions in transportation security systems.

The thesis of this article adopted in the introductory part that the phenomenon of air terrorism over the last few decades has become the greatest threat to air transport safety by direct threat to human life of both travelers and ordinary residents who may die as a result of an act of air terror. Air terrorism has a huge impact on the functioning of the entire human community, by influencing the modification of life on our planet, the processes regulating the social life and mental state of people, which was experienced by the whole world, especially after the 9/11 attacks. It should be emphasized that air terrorism is constantly changing, using both highly qualified and expertly prepared human resources as well as the most modern technical achievements for the purpose of attacks, which significantly hinders counteracting these threats. Only the effort of all the decision-makers responsible for maintaining the safety of air transport and the application of maximum measures for the protection and defense of air traffic will effectively reduce the degree of threat of terrorist attacks directed at air transport.

\section{References}

1. Augustyniak, S. (2008). Prognozy lotnicze $w$ górę. Retrieved from: https://www.pcworld.pl/news/Prognoz y-lotnicze-wgore,140624.html/, 15.05.2020.

2. Puls Biznesu (2007). Do 2025 roku podwoi się liczba latajacych samo-lotami. Retrieved from: https://www.pb.pl/do- 2025-roku-podwoi-sie-liczba-latajacychsamolotami-354104/, 25.05.2020.

3. Domański, J. (1974). 1000 stów o samolocie i lotnictwie. Warszawa: Wydawnictwo MON.

4. O2 (2016). Najgłośniesze porwania samolotów. Retrieved from: https://www.02.pl/galeria/najglosniesze-porwania-samolotow$5977047098122881 \mathrm{~g} / 2 /, 15.05 .2020$.

5. Gotowała, J. (2006). Niepokój w powietrzu - nowe oblicze terroryzmu. In K. Kowalczyk, and W. Wróblewski (Eds.), Terroryzm: Globalne wyzwanie (115-126). Toruń: Wydawnictwo Adam Marszałek.

6. Kingshott, B. (2003). Terrorism: The "New" Religious War. Criminal Justice Studies, 16(1), 15-27. DOI: 10.1080/08884310309603

7. Terror (1989). Terror. In M. Szymczak (Ed.), Stownik języka polskiego, vol. III (p. 498). Warszawa: PWN.

8. Marks, S.P. (2006). Branding the War on Terrorism: Is There New Paradigm of International Law? Michigan State University Journal of International Law, 14(1), 71-119.

9. Wyborcza.pl (2012). Nigeryjski zamachowiec z lotu Delta Airlines dostat dożywocie. Retrieved from https://wyborcza.pl/1,75399,11164004,Niger-

yjski_zamachowiec_z_lotu_Delta_Airlines_dostal.html?disableRedirects $=$ true $/, 25.05 .2020$.

10. RMF.FM (2006). Udaremniono zamach na ogromna skalę. Retrieved from https://www.rmf24.pl/fakty/swiat/new s-udaremniono-zamach-na-ogromnaskale,nId,218653/, 25.05.2020.

11. Wilkinson, P., and Jenkins B.M. (1999). Aviation terrorism and security. London: Frank Cass Publisher.

12. Witkowski, P. (2000). Pojęcie terroryzmu. Cele i metody działań terrorystycznych. In D. Kowalski, and M. Wróblewska (Eds.), Ochrona osób i mienia: Vademecum. Lublin: Wydawnictwo Policealnej Szkoły Detektywów i Pracowników Ochrony O'CHIKARA. 
13. Glen, A. (2010). Reagowanie państwa na zagrożenia terroryzmem lotniczym, Warszawa: AON. 